\title{
Sphingomyelin Phosphodiesterase
}

National Cancer Institute

\section{Source}

National Cancer Institute. Sphingomyelin Phosphodiesterase. NCI Thesaurus. Code C105021.

Sphing omyelin phosphodiesterase ( $629 \mathrm{aa}, \sim 70 \mathrm{kDa}$ ) is encoded by the human SMPD1 gene. This protein plays a role in sphingomyelin catabolism. 